\title{
IS ENVIRONMENTAL ALIGNMENT AND BUSINESS PERFORMANCE: A CONCEPTUAL APPROACH
}

\author{
K. Garg, R.J.O. Joubert and R. Pellissier* \\ School of Business Leadership, UNISA. \\ jouberjo@unisa.ac.za \\ * Demontfort University Southern Africa. \\ rpellissier@dmu.org.za
}

\begin{abstract}
This paper proposes a conceptual model termed "IS environmental alignment" that focuses on the support provided by IS strategy to minimize the gap between perceived environmental uncertainty and realized/objective environmental conditions. The model uses the Chan et al [9] alignment measurement method to measure IS strategic alignment as it provides a quantitative measure. In due course the proposed model would be tested in industry and would examine the affect of IS environmental alignment on business performance. The implication of the model lies in the effective use of deployed IS systems by organizations.

\section{OPSOMMING}

'n Konsepmodel word voorgelê wat handel oor "IS-omgewingsaanpassing". IS-strategieondersteuning by die minimisering van die gaping tussen waargenome omgewingsonsekerheid en gerealiseerde/objektiewe omgewingstoestande. Die model maak gebruik van die Chan et al [9] aanpassingsmeetmetode om IS-strategie-aanpassing op 'n kwantitatiewe basis te bepaal. Met die verloop van tyd sal die konsepmodel in die praktyk getoets word om te toon hoe IS-strategie-aanpassing sakevertoning affekteer. Die effektiewe ontplooiing van IS-stelsels by ondernemings word voorgehou.
\end{abstract}




\section{INTRODUCTION}

The potential of information systems (IS) in supporting organizational activities and helping them to gain competitive advantage has been widely recognized by researchers and the business community [40], and the advancements made in information technology (IT) during the last decade has made it possible to exploit the potential of IT/IS.

IT applications used to help organization gain competitive advantage, reducing competitive disadvantage, or meet other strategic enterprise objectives, referred to as strategic management of information technology, continues to be a key issue in exploiting IT/IS capabilities to achieve higher business performance [14,27,51]. In this context aligning business and IT strategies had been an important issue for researchers during the $90 \mathrm{~s}$ $[24,25,31,32,33]$. However, most of the research is conceptual.

The alignment models developed during the last decade have focused on various dimensions and domains of alignment. For example, Strategic Alignment Model developed by Venkatraman and Henderson [24] focused on four domains namely business strategy, IT strategy, organizational infrastructure and processes, IT infrastructure and processes. Chan and Huff [7] focused on business and information systems strategic orientation. Pankratz [38] highlighted four main areas: business strategy, IT strategy, organizational strategy and culture, and finance strategy. Kanugo et al [26] analyzed the relationship between selected aspects of organization culture and IT strategy in public sector units. Brown and Magill [6] examined the alignment of the IS function with the enterprise.

Based on studies and theoretical framework of key IS management issues that have been conducted for some years in many nations and regions, Gottschalk [22] has predicted four key issues for the $21^{\text {st }}$ century viz; (i) improving links between information systems strategy and business strategy, (ii) developing and implementing an information architecture, (iii) implementing knowledge management systems, and (iv) reducing IT projects' completion time and budget deviations.

Empirical studies of alignment by Chan \& Huff [9] and Luftman [32] mostly examined American and Canadian firms. Kanungo [26] examined public sector units in India. The theories in alignment models emphasize the effective use of IT in the needs of organizations and are achieved by aligning IT facilities with the needs of the organizations. This study deliberates on the support by IS strategy in assessing the uncertainty in the external business environment of an organisation.

\section{LITERATURE REVIEW}

\subsection{Strategic alignment}

Various terms and definitions have been used in literature to describe the concept of business strategy and IT strategy alignment: 'strategic alignment' by Henderson \& Venkatraman [25]; Luftman [33]; Chan \& Huff [7] and Papp [39], 'linkage' by Blaize \& Benbasat [5] and 'harmony' by Woolfe \& Cash [50].

For Woolfe \& Cash [50] 'strategic alignment' occurs when a company has harmonized its overall strategy and its information technology systems. 
Chan \& Huff [7] explains that organizations typically achieve 'strategic alignment' by passing through three levels: Awareness, Integration and Alignment. The awareness level indicates that the firm has reached a level of awareness in recognizing and acting upon the importance of having information systems more closely connected with the business. The second level is concerned with integrating operational business and IS plans and activities, the final level (strategic alignment level) concerns integrating IS with the organization's fundamental strategies and core competencies.

Blaize and Benbasat [5] indicate that information technology management can be conceptualized as a problem of coordinating the relationship between the business domain and IT domain. In this context, information systems planning is only one of several mechanisms that can be utilized to accomplish this task. A comprehensive treatment of this issue has been labeled as 'linkage'.

Papp [39] defines 'strategic alignment' as the appropriate use of information technology in the integration and development of business strategies and corporate goals.

In essence, four sets of decisions by an organization - on business strategy, IT strategy, business infrastructure, and IT infrastructure - need to be coordinated or aligned [33].

The various models of alignment identified alignment of IT/IS strategy with business strategy to achieve competitive advantage. The most popular is strategic alignment model (SAM) developed by Henderson \& Venkatraman in $1990 .{ }^{1}$

\subsection{Environmental Uncertainty}

An organization has both an external and internal environment. According to Wheelen and Hunger [49], the external environment consists of variables that are outside the organization and not typically within the short-run control of top management, while internal environment consists of variables that are within the organization itself and usually within the short-run control of top management. The internal environment of an organization consists of structure, culture and resource related issues [49]. While the external environment consists of two layers, the level closest to the organization is the task environment which includes sectors such as competitors, suppliers, customers, government, labour unions etc; and the other layer is called general environment or societal environment, which often includes sociocultural, political, technological, and economic forces, and affects organization indirectly. (See Kumar [28]; Wheelen \& Hunger [49]).

Most researchers have settled upon the task environment as the primary source of forces to which organizations must respond, and task environment have been investigated with respect to a number of potential important dimensions. (see Miles \& Snow [35]).

Duncan [16] identified two characteristics or dimensions of environment viz. complexity and variability. Complexity means the number of environmental elements, and the level of interdependence between these elements. Variability refers to the changes in the environment

\footnotetext{
${ }^{1}$ For details on review of strategic alignment refer 'Review of Strategic Alignment: its meaning, measurement and impact on business performance' (Garg, A.K., Joubert, R.J.O and Pellissier, R., 2002. unpublished research paper, SBL UNISA).
} 
that create a large number of potential outcomes, thus decreasing confidence in prediction. Miller [36] identified three dimensions of environment i.e. dynamism, heterogeneity and hostility. Ansoff and Sullivan [1] defined environmental turbulence as a measure of the degree of changeability or discontinuity and predictability of the firm's environment.

Complexity has been studied under different labels, including effect uncertainty by Milliken [34], predictability by Duncan [16] and Miles \& Snow [35] and heterogeneity by Miller [36].

Variability has been studied under labels of; dynamism by Miller [36] and Duncan [16]; and turbulence by Sambamurty et al [42] and Ansoff \& Sullivan [1].

Langford \& Hunsicker [29] based on the past research identified three basic perspectives that have evolved since 1950 to define and measure the environment: the objective environmental perspective, the perceived environmental perspective, and the enacted environmental perspective. According to them the researchers with objective environmental perspective assume the organization and environment are real and separate. Therefore, strategists must conduct an environmental analysis by scanning the objective, existing environment for opportunities and threats. This perspective dominates strategic management in the content of textbooks. External analysis is combined with internal analysis; the SWOT analysis, followed by mission; objectives and strategy formulation are the well-known issues in this respect.

The perceived environmental perspective also considers the environment to be external, real, and material, instead the difference between objective and perceived environment involves a distinction about strategists (see Smircich \& Stubbart, [43]). To Miles and Snow [35] perceived environmental uncertainty refers to predictability of conditions in the organization's environment.

According to Duncan [16] uncertainty arises due to the incomplete knowledge of the objective environment. It is the assessment of strategists about environmental conditions that is subjective and hence a perceptual phenomenon, rather than objective assessment of environmental conditions, Milliken [34].

The enacted environmental perspective suggests that there is no separate objective environment and organization.

Some of the investigators have not distinguished between rate of environmental change and degree of uncertainty and have therefore implicitly equated the two dimensions of environment. It is possible to have rapid but largely predictable change in the environment, and under such circumstances the organization does not actually confront uncertainty [35]. It is not change per se, or even a fast rate of change, that creates uncertainty about the environment; rather it is unpredictable change that will be associated with environmental uncertainty (see Milliken [34]).

Duncan [16] was the first to initiate the study of environmental uncertainty as perceptual phenomenon. In uncertain situations the individuals can still assign probability to the outcome of events, but the respondent is less confident about the probability estimates than under conditions of risk. The question then is how sure or confident the respondent is in his probability estimates, i.e. in uncertain situation there is less predictability with respect to the outcome of events than under conditions of risk. A major emphasis of research has been on 
perceived environmental uncertainty and the subjective, rather than objective, data generated and utilized by strategic decision makers [18].

Miles \& Snow [35] reported that uncertainty 'perceived' by managers, influences organizational responses more directly than does 'objectively' determined uncertainty.

Considering the quantum of research on perceived uncertainty, this research has proposed to use subjective criteria for measuring the environmental uncertainty.

\subsection{IS Strategy}

Information is seen as valuable, but information systems (IS) function is not seen as equally valuable (see Avison et al [2]). Information management has emerged as the most common brief name for the management of the use of information technology in an organization [18]. According to Earl [17] the information management (IM) strategy is concerned with the role and structure of IT activities in the organization and it focuses on relationships between what do we do with technology (IS strategy) and how do we do it (IT strategy). The IM strategy is the management framework, i.e. guidelines for organizational IS/IT activities from a longterm perspective. All three are interlinked, however, the IT strategy focus on technical solutions and IS strategy reflects the organization's need. Figure 1 shows the relationship between IS strategy, IT strategy and IM strategy.

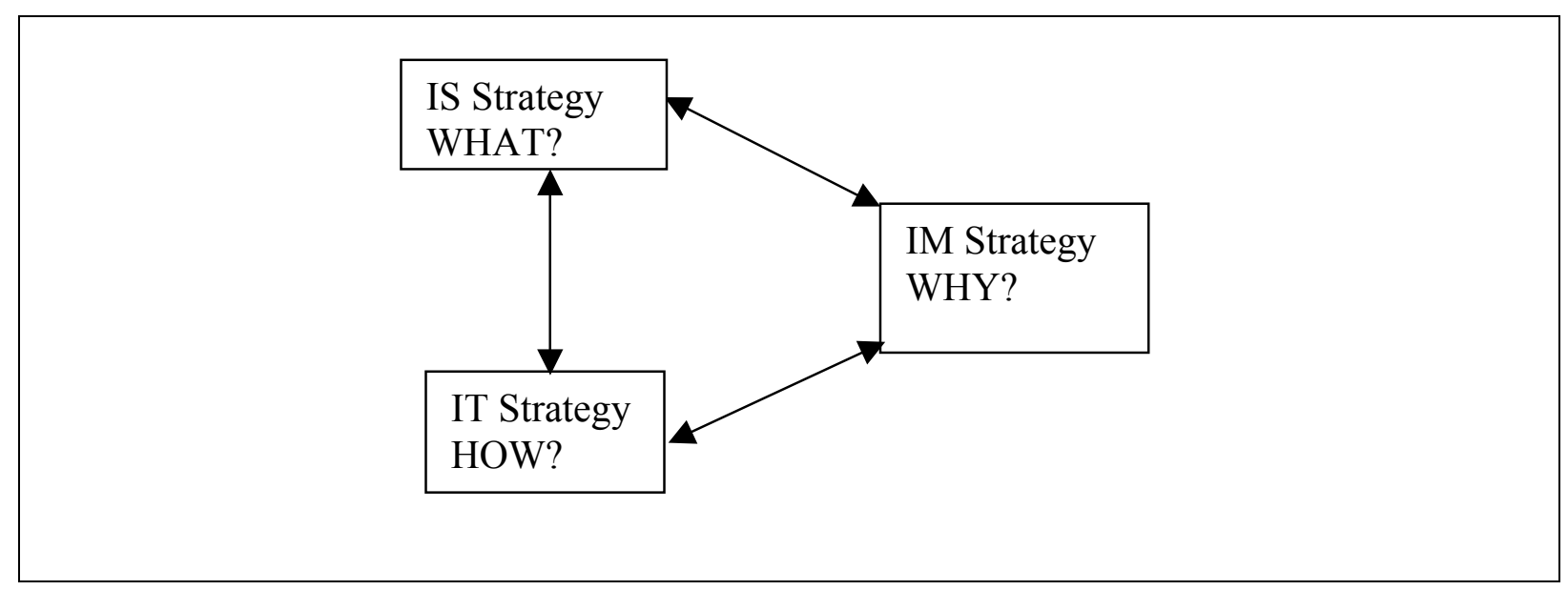

Fig 1: Relationship between IS strategy, IT strategy and IM strategy, Earl [17]

Based on the research of Henderson and Venkatraman [24], Chan et al [11] identified three dimensions of IS strategy - the type and capabilities of IS, the IS support provided for business strategy and IS governance issues. Zhang \& Lado [51] identified IS as an effective and efficient tool for gathering and processing information of strategic importance from external sources.

This study considers the IS support dimension of IS strategy for assessing the external sources - specifically the external environment. 


\section{STUDIES ON ENVIRONMENTAL UNCERTAINTY, IT AND BUSINESS PERFORMANCE}

Bergeron et al [4] considered the IT environmental alignment for 110 small and medium sized enterprises (SMEs) and concluded that environment-technology fit, whatever the bivariate approach taken, does not appear to predict or explain performance. They explain that this may be related to specificity of the small business context. The more intuitive, judgment and experimental rather than analytical management/decision style of small firm owner-managers does not lead them to increase their firm's information processing capability in response to increased turbulence in their environment, but to respond more in structural terms e.g. hiring managers and/or professionals and delegating to them tasks that require specialization [37].

Other studies dealing with environment and information systems include the following:

a) Information systems planning in a turbulent environment by Salmela, Lederer and Reponen. [41]: The study examined the two competing theories of effective planning in a turbulent environment in two organizations that use different approaches. One organization practiced formal and comprehensive IS planning, while the other had relied more on an informal and incremental approach. The study contributes to practice by showing IS planners the importance of understanding their environment and also the potential of comprehensive planning practice.

b) The comprehensiveness of IT planning: A contingency approach by Sambamurty et al [42]: The study used a contingency model to suggest that the level of environmental complexity and turbulence and the level of existing consensus in the planning group influences the relationship between process comprehensiveness and planning performance.

c) The Impact of Environment on the Management of Information Systems by Lederer and Mendelow. [30]: It emphasizes the need to study the impact of environment on the management of IS. The study reveals that IS managers develop coping mechanisms either to resolve the problems directly or to influence the environment to prevent the problems and IS management is becoming more anticipatory.

The above three studies does not link their models to business performance.

\section{THE CONCEPTUAL MODEL}

\subsection{Strategic alignment, Structural alignment and IS environmental alignment:}

The research on environmental uncertainty converge on three key issues viz. i) task environment is the primary force that organizations must respond to, ii) it is the unpredictability of change that will be associated with environmental uncertainty, and iii) the measurement of environmental uncertainty is a subjective phenomenon [1,16,18,34,35]. Correct assessment of environment is related to organization effectiveness i.e. organizations that perceive the objective environment incorrectly will be less effective (see Galbraith [20]). However, uncertainty arises due to imperfect and incomplete knowledge of the objective environment [16]. Thus, strategists must first minimize the gap between their flawed perceptions and the objective environment (see Smircich \& Stubbart [43]), and use the analysis to identify the perceived opportunities and threats [29]. 
The above indicate two aspects; the first to minimize the gap between perceived and objective environment/realized environmental conditions (for example an executive perceived the Rand/ $\$$ exchange rate at 9.5 by the end of 2001 , however the realized rate was 12.5 ), and second to identify opportunity and threats and acting on them. The issue of identifying opportunities and threats and acting accordingly is the area of business strategy. In this context aligning business strategy and IT/IS strategy to leverage IT for competitive advantage is referred to as strategic alignment for strategic management of IT by Venkatraman \& Henderson [24].

Organizations have made substantial investment in information technology (hardware, software \& communication) to enhance the information processing and predicting capabilities of their information systems or IS. IS may serve as an effective and efficient tool for gathering and processing information of strategic importance from external sources e.g. customers, suppliers and dealers, explains Zhang and Lado [51]. They further explain that with online access to various external databases, executive information systems enable managers to search and retrieve more external information about its suppliers, customers, competitors, financial organizations, stakeholders, regulatory bodies, and interest groups, etc. in a timely manner.

A grouping consisting of suppliers, customers, competitors etc. is classified as task environment by various researchers $[28,49]$ and are the primary source of forces to which organizations must respond. Hence, IS strategy could play a significant role; in minimizing the gap between perceived environmental uncertainty and the objective/realized environmental conditions, by providing support to strategist in assessing the environmental conditions.

To realize maximum benefits from IS strategy, alignment of IS strategy (its support dimension) and the assessment of perceived environmental uncertainty is essential. This alignment is referred to, as IS environmental alignment in this study. The strategic alignment [24] and structural alignment [10] are basically business unit level issues, while IS environmental alignment would primarily be corporate level issue. The IS environmental alignment becomes highly important for business due to substantial investment in IT and uncertainty in business environment.

The different alignment models are summarized in table 1: 


\begin{tabular}{|l|l|l|}
\hline Models of Alignment & Elements of Alignment & Focus \\
\hline $\begin{array}{l}\text { Strategic Alignment model } \\
\text { (Henderson \& Venkatraman } \\
\text { [24]), IS strategic Alignment } \\
\text { model (Chan\& Huff [7,8,9]) }\end{array}$ & $\begin{array}{l}\text { Business strategy, IT/IS } \\
\text { strategy, business } \\
\text { infrastructure \& IT } \\
\text { infrastructure }\end{array}$ & $\begin{array}{l}\text { Priorities and activities of } \\
\text { Business strategy, priorities } \\
\text { and activities of IT/IS } \\
\text { strategy and business } \\
\text { performance }\end{array}$ \\
\hline $\begin{array}{l}\text { IS Structural Alignment } \\
\text { (Chan [10]) }\end{array}$ & $\begin{array}{l}\text { Business unit structure and } \\
\text { Structure of IS functions }\end{array}$ & $\begin{array}{l}\text { Such as the (in) } \\
\text { appropriateness of the IS } \\
\text { function's position within } \\
\text { the enterprise, IS reporting } \\
\text { relationships, and (de) } \\
\text { centralization of IS services } \\
\text { and infrastructure }\end{array}$ \\
\hline $\begin{array}{l}\text { IS environmental } \\
\text { alignment (proposed } \\
\text { model) }\end{array}$ & $\begin{array}{l}\text { Perceived environmental } \\
\text { uncertainty (of task } \\
\text { environment) and IS } \\
\text { strategy }\end{array}$ & $\begin{array}{l}\text { Focus on the support } \\
\text { provided by IS strategy to } \\
\text { minimize the gap between } \\
\text { perceived environmental } \\
\text { conditions and } \\
\text { realized/objective } \\
\text { environmental conditions, } \\
\text { and business performance }\end{array}$ \\
\hline
\end{tabular}

Table 1: Various models of alignment

\subsection{IS environmental alignment model}

All the models of alignment (refer table 1) consider the effective use of IT in business, or how much IT/IS complement business. Theory in the models can be explained with an example of a fresh fruit or meat hawker who would surely make more profits if he invests in a calculator and electronic weighing machine and uses it. This is due to the nature of product he is selling. He would be better of if he further invests in an electronic organizer and feeds his daily sales and other data for various use, like estimating next day sales, collection of debt etc. Similar will be the case for any other business, business performance would be better, if IT/IS investments made, are effectively used or aligned with organizational needs. Conversely, in a model of alignment, business performance would be predicted better by effective use of IT/IS as compared to directly related factors of alignment.

'Unpredictability' of an environmental factor refers to 'unpredictability of change' of the factor and is the measure of uncertainty associated with the factor. It is logical that the unpredictability of an environmental factor would be related to the gap in the perceived and realized environmental condition. This would mean higher unpredictability of an environmental factor would result in higher gap as compared to an easily predictable factor. IS support in assessing the uncertainty would help in reducing the gap. Higher IS support would be required for higher gap situation in perceived and realized conditions. However, this gap cannot be reduced to zero in practical situations. The implication of the above is explained in Table 2. 


\begin{tabular}{|c|c|c|c|c|}
\hline $\begin{array}{l}\text { Perceived } \\
\text { uncertainty of an } \\
\text { Environmental } \\
\text { Factor (as } \\
\text { measured by } \\
\text { unpredictability } \\
\text { of change) }\end{array}$ & $\begin{array}{l}\text { Gap between } \\
\text { perceived } \\
\text { uncertainty and } \\
\text { realized } \\
\text { environmental } \\
\text { conditions } \approx \\
\text { Environmental } \\
\text { Factor } \\
\text { uncertainty }\end{array}$ & $\begin{array}{l}\text { IS support provided } \\
\text { in reducing the gap } \approx \\
\text { IS support in } \\
\text { perceiving/assessing } \\
\text { the factor uncertainty }\end{array}$ & $\begin{array}{l}\text { Effectiveness } \\
\text { of IT use }\end{array}$ & $\begin{array}{l}\text { IS } \\
\text { environmental } \\
\text { Alignment }\end{array}$ \\
\hline High * & $\begin{array}{l}\text { High } \\
\text { High }\end{array}$ & $\begin{array}{l}\text { High } \\
\text { Low }\end{array}$ & $\begin{array}{l}\text { Effective } \\
\text { Ineffective }\end{array}$ & $\begin{array}{l}\text { Good } \\
\text { Poor }\end{array}$ \\
\hline Low $* *$ & $\begin{array}{l}\text { Low } \\
\text { Low } \\
\end{array}$ & $\begin{array}{l}\text { High } \\
\text { Low }\end{array}$ & $\begin{array}{l}\text { Waste } \\
\text { Effective }\end{array}$ & $\begin{array}{l}\text { Bad/superim- } \\
\text { posed } \\
\text { Good }\end{array}$ \\
\hline
\end{tabular}

*Say 6 on rating scale of 1-7,** Say 2 on rating scale of 1-7

Table 2: Effectiveness of IT use and its implication on alignment

Based on the above logic IS environmental alignment model is conceptualized in figure 2.

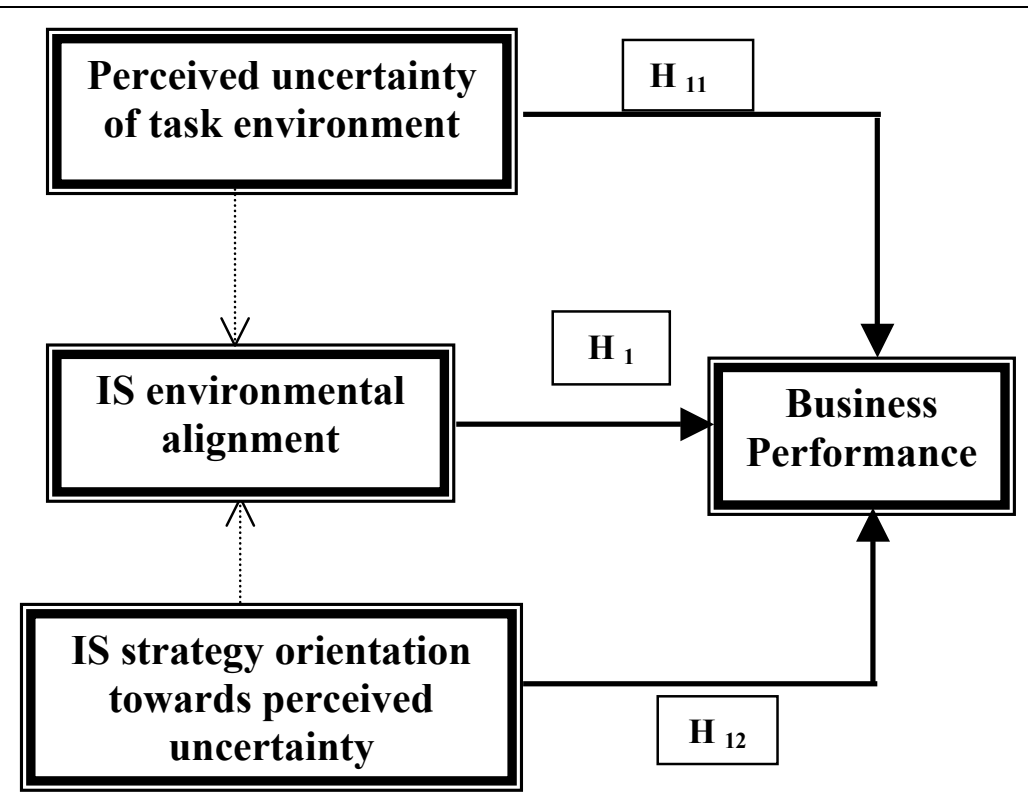

Note: Alignment measurement after Chan et al[9]

\section{Fig 2: IS environmental alignment model}

The model uses the environmental alignment theory as above and uses the alignment measurement proposed by Chan et al [9], as it provides a quantitative measure of alignment.

IS strategy orientation towards perceived uncertainty is the support provided by the information systems that had been used by the organization, to reduce the gap between perceived environment and realized environmental conditions. (i.e. IS support in perceiving/assessing environmental factor uncertainty). 
IS environmental alignment is the degree of fit between perceived uncertainty of task environment and IS strategy orientation towards perceived uncertainty. The alignment measures the effective use of IS by the organization.

The above model hypothesize the following:

The IS environmental alignment has positive effect on business performance $\left(\mathrm{H}_{1}\right)$ and this effect is more pronounced than the effect of perceived uncertainty of the task environment on business performance $\left(\mathrm{H}_{11}\right)$ and effect of IS support on business performance $\left(\mathrm{H}_{12}\right)$.

The objectives are to measure the $\mathrm{H}_{1}, \mathrm{H}_{11}$ and $\mathrm{H}_{12}$ using Partial Least Square (PLS) methodology.

The above would require:

(i) Measuring the variables a) perceived environmental uncertainty (PENV), b) IS strategy orientation (ISS) and c) business performance (BP) independently.

(ii) Calculating IS environmental alignment (ISA) from the measurements of PENV and ISS, and

(iii) Predicting BP from PENV, ISS \& ISA (predictor variable) to find out the affect of each on BP.

(iv) Finding the error in predicted and measured value of BP.

\subsection{Justification for Research Methodology}

In the past few years, the IS field has seen a substantial increase in the number of submissions and publications using structural equation modeling (SEM) techniques [13]. SEM techniques such as LISREL and Partial Least Squares (PLS) are second-generation data analysis techniques that can be used to test the extent to which IS research meet recognized standards for high quality statistical analysis. Contrary to first generation statistical tools such as regression, SEM enables researcher to answer a set of interrelated questions in a single, systematic and comprehensive analysis, by modeling the relationships among multiple independent and dependent constructs simultaneously. This capability for simultaneous analysis differs greatly from first generation regression models such as linear regression, LOGIT, ANOVA, and MANOVA, which can analyze only one layer of linkage between independent and dependent variables at a time, reported by Gefen, Straub, and Boudreau [21].

A comparative analysis between SEM, PLS and Linear Regression is presented in table 3. $[12,21,23,44,45,46,47,48]$. 


\begin{tabular}{|c|c|c|c|}
\hline Issues & LISREL & PLS & Linear Regression \\
\hline Based on & $\begin{array}{l}\text { Covariance-based } \\
\text { SEM }\end{array}$ & Partial-least-squares & Linear regression \\
\hline Required theory base & $\begin{array}{l}\text { Requires sound } \\
\text { theory base. } \\
\text { Supports } \\
\text { confirmatory } \\
\text { research. }\end{array}$ & $\begin{array}{l}\text { Does not necessarily } \\
\text { require sound theory } \\
\text { base. Supports both } \\
\text { exploratory and } \\
\text { confirmatory research. }\end{array}$ & $\begin{array}{l}\text { Does not necessarily } \\
\text { require sound theory } \\
\text { base. Supports both } \\
\text { exploratory and } \\
\text { confirmatory research. }\end{array}$ \\
\hline Assumed Distribution & $\begin{array}{l}\text { Multivariate } \\
\text { normal }\end{array}$ & $\begin{array}{l}\text { Relatively robust to } \\
\text { deviations from a } \\
\text { multivariate } \\
\text { distribution. }\end{array}$ & $\begin{array}{l}\text { Relatively robust to } \\
\text { deviations from a } \\
\text { multivariate distribution, } \\
\text { with established method } \\
\text { of handling non- } \\
\text { multivariate } \\
\text { distributions. }\end{array}$ \\
\hline $\begin{array}{l}\text { Required minimal Sample } \\
\text { Size }\end{array}$ & $\begin{array}{l}\text { At least 100-150 } \\
\text { cases }\end{array}$ & $\begin{array}{l}\text { At least } 10 \text { times the } \\
\text { number of items in the } \\
\text { most complex } \\
\text { construct. }\end{array}$ & $\begin{array}{l}\text { Supports smaller sample } \\
\text { size, although a sample } \\
\text { of at least } 30 \text { is required. }\end{array}$ \\
\hline $\begin{array}{l}\text { Maps paths to many } \\
\text { dependent (latent or } \\
\text { observed) variables in same } \\
\text { research model and analyze } \\
\text { all the paths simultaneously } \\
\text { rather than one at a time }\end{array}$ & Supported & Supported & Not supported \\
\hline $\begin{array}{l}\text { Maps specific and error } \\
\text { variance of the observed } \\
\text { variables into research } \\
\text { model }\end{array}$ & Supported & Not supported & Not supported \\
\hline $\begin{array}{l}\text { Maps reflective observed } \\
\text { variables }\end{array}$ & Supported & Supported & Supported \\
\hline $\begin{array}{l}\text { Maps formative observed } \\
\text { variables }\end{array}$ & Not Supported & Supported & Not Supported \\
\hline $\begin{array}{l}\text { Analyzes all the paths, both } \\
\text { measurement and structural } \\
\text { in one analysis }\end{array}$ & Supported & Supported & Not supported \\
\hline $\begin{array}{l}\text { Can perform a } \\
\text { confirmatory factor } \\
\text { analysis }\end{array}$ & Supported & Supported & Not supported \\
\hline $\begin{array}{l}\text { Analysis of Individual item } \\
\text { loading paths }\end{array}$ & Provided & Provided & Not provided \\
\hline $\begin{array}{l}\text { Significance estimation } \\
\text { methods }\end{array}$ & $\begin{array}{l}\text { Require } \\
\text { parametric } \\
\text { assumptions }\end{array}$ & $\begin{array}{l}\text { Does not require } \\
\text { parametric } \\
\text { assumptions }\end{array}$ & $\begin{array}{l}\text { Does not require } \\
\text { parametric assumptions }\end{array}$ \\
\hline
\end{tabular}

Table 3: Comparative analysis of PLS, LISREL and Linear Regression

Based on the analysis presented in table 3, PLS method is proposed for the study due to the reasons supported for this research construct.

\subsection{Mathematical representation of the model using Partial least Squares (PLS):}

Using PLS terminology the model is represented in figure 3. 


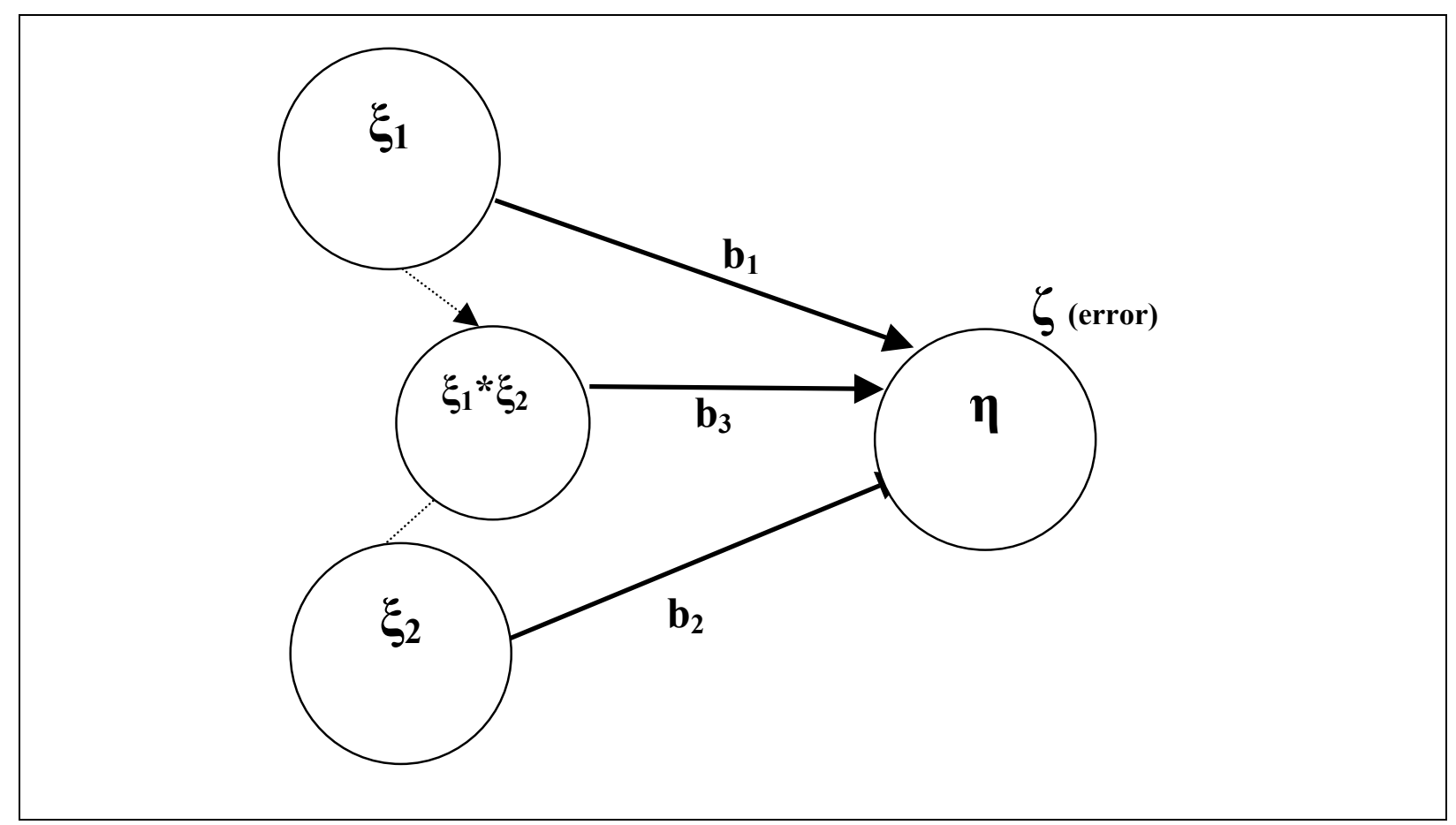

Fig3: Mathematical representation of the conceptual model

The examination condition can be represented mathematically as below: $\eta=b_{1} * \xi_{1}+b_{2} * \xi_{2}+b_{3} * \xi_{1} * \xi_{2}+\zeta$ and, according to alignment theory $b_{3}$ should be greater than $\mathrm{b}_{1}$, and $\mathrm{b}_{3}$ should be greater than $\mathrm{b}_{2}$. $\xi_{1} * \xi_{2}$ represents moderation type of alignment fit [9]. The above is the basic equation, for the model.

PLS would be used for the study for reasons explained in previous section. Although the PLS method analyses measurement and structural estimates together, the PLS model is analyzed in two stages: (i) the assessment of the reliability and validity of the measurement model, and (ii) the assessment of the structural model. The sequence ensures that we have reliable and valid measures of constructs before attempting to draw conclusions regarding the relationship among the construct [3].

Assessment of the measurement model also referred to as the outer model: This examines how each block of indicators relates to its latent variable [12]. The measurement model would be assessed by examining; individual item reliability, internal consistency, and discriminant validity.

Assessment of the structural models also called inner model: This depicts the relationship among latent variables based on substantive theory [12].

Using PLS size of path coefficients b1, b2, b3 error $\zeta$ would be calculated. Statistical significance for the path coefficients would be carried out using Jackknifing, or blindfolding, depending on the software version to be used. $\mathrm{R}^{2}$ would be estimated to explain the variance in dependent construct i.e. business performance. 


\section{CONTRIBUTION TO BODY THEORY}

In the information systems area, the relationship between environment, IT and performance has not received much attention and environmental uncertainty has, however, been included as a contingency variable in models of IT-structure and IT-strategy, but results on business performance are mixed. Relationship between IT management, organisation structure and performance was found to be unaffected by environmental uncertainty by a study, while another study found the impact of external factors influenced the facilitators of strategic IS alignment [4].

Considering environmental uncertainty as an independent variable and analyzing empirical data, this study would contribute towards the relationship between environmental uncertainty, IS strategy and business performance. The research would indicate that the synergy of IS systems with environmental uncertainty is necessary to derive benefit from the investment in IT.

\section{LIMITATIONS}

The model proposed here is a conceptual model. The ultimate goal of the research is to develop an 'Environmental Uncertainty Dashboard' (EUD) that would measure and reflect external business environmental uncertainty. The applicability of this model would be limited to provide theoretical background for the development of EUD.

The research would use views (data) provided by the senior executives of the company. However, studies suggest perceptual data/views from senior executives tend to correlate strongly with objective data [15].

\section{CONCLUSION AND FURTHER STUDY}

Organizations need to expand the scope of IS applications to the various requirements. IS environmental alignment shows the effective use of IS in organizations in the area of environmental uncertainty.

Further research is on to test the model and to achieve the ultimate objective of development of EUD.

\section{REFERENCES}

[1] Ansoff, H. I. and Sullivan, P.A. 'Optimizing Profitability in Turbulent Environments: A formula for Strategic Success'. Long Range Planning, 26 (5) pp. 11-23 (1993)

[2] Avison, D.E., Cuthbertson, C.H. and Powell, P. 'The paradox of Information Systems: Strategic value and low status'. Journal of Strategic Information Systems, 8 (1999)

[3] Barclays, D., Higgins, C. and Thompson, R. 'Partial Least Square Squares (PLS) Approach to Causal Modeling: Personal Computer Adoption and Use as an Illustration' (with Commentaries), Technology Studies, 2(2) (1995)

[4] Bergeron, F., Raymond, L., and Rivard, S. 'The concept of Fit in Information Systems Research'. Available from http://www.fsa.ulaval.ca/rd [Accessed on Nov 19, 2001] (1999) 
[5] Blaize, H.R., Benbasat, I. 'Measuring the linkage between business and information technology objectives', MIS Quarterly, 20(1). Available from Expanded Academic ASAP Int'1 Ed. UNISA Library [Accessed on July 5, 2001] (1996)

[6] Brown, C.V. and Magill, S.L. 'Alignment of the IS function with the enterprise: towards a model of antecedents'. MIS Quarterly. 14(8). Available from http://web2.infotrac.London.gal/purl [Accessed on $7^{\text {th }}$ May 2001] (1994)

[7] Chan, Y.E., Huff, S.L. 'Strategic information systems alignment', Business Quarterly, 58(1). Available from Expanded Academic ASAP Int'l Ed. UNISA Library [Accessed on July 5, 2001] (1993)

[8] Chan, Y.E. and Huff, S.L. 'Investigating information systems strategic fit: A novel approach'. Working paper no 93-11, Queen's School of Business, Canada (1993)

[9] Chan, Y.E, Huff, S.L., Barclay, D.W. and Copeland, D.G. 'Business Strategic Orientation, Information systems strategic orientation, and strategic alignment', Information Systems Research, 8(2) (1997)

[10] Chan, Y. E. 'Aligning Business and Information Systems Strategy and Structure: Eight Case Studies' Working paper no 97-07. Queen's School of Business, Canada (1997)

[11] Chan, Y.E, Huff, S.L., Barclay, Copeland, D.G. 'Assessing Realized information Systems Strategy', Journal of Strategic Information Systems, 6 (1998)

[12] Chin, W.W. 'The Partial Least Square Approach to Structural equation Modeling' in Modern Methods for Business Research Modeling, edited by Marcoulides G.A., Lawrence Erlbaum Associates, Publisher, New Jersey (1998)

[13] Chin, W.W. 'Issues and Opinion Structure Equation Modeling (Commentary)'. Management Systems Quarterly. Available from http://misq.org/archivist/vol/no22/issue1/vol22n1comntry.html [Accessed on December 16, 2001] 22(1) (1998)

[14] Croteau, A.M. and Bergeron, F. 'An information technology trilogy: business strategy, technological deployment and organizational performance'. Journal of Strategic Information Systems, 10 (2001)

[15] Dawes, J. 'The Relationship between Subjective and Objective Company Performance Measures in Market Orientation Research: Further Empirical Evidence'. Available from http://marketing-bulletin.massey.ac.nz [in press, Accessed on $19^{\text {th }}$ April 2002] (1999)

[16] Duncan, R. B. 'Characteristics of Organizational Environments and Perceived Environment Uncertainty'. Administrative Science Quarterly, 17 (1972)

[17] Earl, M.J. Management Strategies for Information Technology. Prentice Hall, New York (1989)

[18] Ebrahimini, B.P. ' Perceived Strategic Uncertainty and Environment Scanning Behaviour of Hong Kong Chinese Executives'. Journal of Business Research. 49 (2000)

[19] Frishammar, J. 'Characteristics in information processing approaches'. International Journal of Information Management, 22 (2002)

[20] Galbraith, J.R. Designing Complex Organizations. Reading, Mass: AddisonWesely (1973)

[21] Gefern, D., Straub, D. W. and Boudreau, M.C. 'Structural Equation Modeling and Regression: Guidelines for research Practice'. Communication of the Association for Information Systems, 4(7) (2000)

[22] Gottschalk, P. 'Studies of key issues in IS management around the world'. International Journal of Information Management, 20 (2000) 
[23] Hair, J.F., Anderson, R.E., Tatham, R.L., Black, W.C. Multivariate Analysis, $5^{\text {th }}$ ed. Prentice Hall, New Jersey (1998)

[24] Henderson, J. and Venkatraman, N. 'Strategic Alignment: A Model for organizational transformation via information technology'. Sloan School of Management, MIT, Working paper No 217 (1990)

[25] Henderson, J. and Venkatraman, N. 'Strategic Alignment: Leveraging information technology for transforming organizations', IBM systems journal, 32 (1) (1993)

[26] Kanungo, S., Sadavarti, S., and Sriniwas, Y. 'Relating IT strategy and organizational culture: an empirical study of public sector units in India'. Journal of Strategic Information Systems, 10 (2001)

[27] Kearns, G.S., Lederer, A.L. 'The effect of strategic alignment on the use of ISbased resources for competitive advantage'. Journal of Strategic Information Systems, 9 (2000)

[28] Kumar, K. 'Perceived Uncertainty: How Different Environmental Sectors Moderate Strategy - Performance Relationships’. Available from http://blue.temple.edu/ eastern/eam1997/kumar.html [Accessed on Nov 27, 2001] (1997)

[29] Langford, B.E., and Hunsicker, F.R. 'An Integrated View of the Relationship Between the Organization and Its Environment'. Available from http://www.westga.edu/ bquest/1996/model.html [Accessed on August 10,2001] (1996)

[30] Lederer A.L. and Mendelow, A.L. 'The Impact of the Environment on the Management of Information Systems'. Information Systems Research, 1(2) (1990)

[31] Luftman, J., Papp R., and Brier T. 'Enablers and inhibitors of business-IT alignment', Communications of Association for Information Systems (AIS), 1 (1999)

[32] Luftman, J. 'Aligning Business-IT Alignment Maturity', Communications of Association for Information Systems (AIS) , 4 (2000)

[33] Luftman, J. 'Introduction'. In: Luftman J. Competing in the information age: Strategic Alignment in Practice. New York: Oxford University Press (1996)

[34] Milliken, F.J. 'Three Types of Perceived Uncertainty About the Environment: State, Effect and Response Uncertainty.' Academy of Management Review. 12(1) (1987)

[35] Miles, R.E. and Snow, C.C. Organizational Strategy, Structure, and Process. Mc Grow-Hill Inc, New York (1978)

[36] Miller, D. 'The Structure and Environmental Correlates of Business Strategy'. Strategic Management Journal, 8 (1987)

[37] Miller, D. and Droge, C. 'Psychological and Traditional Determinants of Structure'. Administrative Science Quarterly, 31 (1986)

[38] Pankratz, H. 'Strategic Alignment: Managing for Synergy'. Business Quarterly. 55(3) (1991)

[39] Papp, R. 'Business and IT strategic alignment: New perspectives and assessment' Available from http://hsb.baylor.edu/ramsower/acis/papers/papp.htm [Accessed on June 4, 2001] (1995)

[40] Peters, S.C.A., Heng, M.S.H. and Vet, R. 'Formation of the information systems strategy in global financial services company'. Information and Organization, 12 (2002)

[41] Salmela, H., Lederer, A.L. and Reponen, T. 'Information systems planning in a turbulent environment'. European Journal of Information Systems, 9 (2000)

[42] Sambamurty, V., Zmud, R.W., and Byrd, T. A. 'The Comprehensiveness of IT Planning Process: A Contingency Approach'. Journal of Information Technology Management, 5(1) (1994) 
[43] Smircich, L. \& Stubbart, C. 'Strategic Management in an Enacted World'. Academy of Management Review, 10(4) (1985)

[44] Straub, D.W. ' Validating Instruments in MIS Research'. MIS Quarterly. (1989)

[45] Structural Equation Modeling, Path Analysis, Multiple Regression. Available from http://www.chass.ncsu.edu/grason/pa765 [Accessed on December 4,2001]

[46] http://www.ssicentral.com/liserel/exsim5.htm 'Confirmatory Factor Analysis' [Accessed on December 11,2001]

[47] http://www.ssa.com/rnd/app/da/new/dapls.html 'An introduction to Partial Least Squares and Examples using the PLS procedure.' [Accessed on December 27, 2001].

[48] Thomson, R.L., Higgins A.C. and Hovel, J.M. 'Personal Computing: Towards a conceptual Model of Utilization'. MIS Quarterly (1991)

[49] Wheelen, T.L. and Hunger J.D. 1998. Strategic Management and Business policy, Entering $21^{\text {st }}$ century global society. Published by Addison- Wesley Longman, Inc. USA (1998)

[50] Woolfe, R., and Cash, J. 'IT gets in line with a company's IS and business goals in Syn. The gains can be huge', Information week Available from Expanded Academic ASAP Int'1 Ed. UNISA Library [Accessed on Sept11, 2001] (1992)

[51] Zhang, M.J. and Lado, A.A. 'Information systems and competitive advantage: a competency-based view'. Technovation. Available from www.elsevier.com/locate/technovation [Accessed on 3rd May 2002], 21 (2001) 